\title{
Public Transportation Services in Oman: A Study of Public Perceptions
}

\author{
Rakesh Belwal and Shweta Belwal \\ Sohar University, Oman
}

\begin{abstract}
Public transportation services are vital for civic life. Recently, many countries in the Middle East have turned their attention towards developing and improving their public transport systems, as problems such as traffic congestions in cities, low mobility, high individual costs of transport, and a rural-urban divide in services have arisen. This study is a public needs assessment and opinion survey of an area in one such Middle Eastern country, the Al-Batinah region of Oman. The study finds public transport services in Oman are minimal and do not match demand, and there is an excessive reliance on private cars. Marketing of public transport services is constrained by certain environmental issues, particularly the socio-cultural and physical environments. The study is innovative from both an approach and implementation perspective and will help policy makers in Oman think about long-term strategies towards establishing viable public transport solutions.
\end{abstract}

\section{Introduction}

Public transportation services are integral to societies. Countries need effective public transport services for transit users, apparent or latent, who need and value different modes of public transport. Public transportation is defined as transportation by a conveyance that provides continuing general or special transportation 
to the public. It excludes school buses and charter and sightseeing services and includes various modes such as buses, subways, rails, trolleys, and ferry boats (Tran and Kleiner 2005). In an urbanized society, an efficient transportation system is one of the basic components of the social, economic, and physical structure, and it has to be competitive and attractive to the transit seekers. To be well regarded, public transport services must follow regular schedules, be safe and rapid, guarantee high service quality, and utilize resources efficiently (Dridi et al. 2005).

Public transportation services vitalize economies of nations. These services improve the life of communities by providing safe, efficient, and economic transport; they ensure personal mobility through making available cost effective modes; and they benefit society by easing traffic congestion, saving money, and creating and sustaining jobs (Tran and Kleiner 2005). Every day in the U.S., publicly-funded transportation systems provide approximately 32 million passenger trips. These systems serve commuters, students, tourists, seniors, persons with disabilities, and others who rely on trains, buses, ferries, vans, and other accessible vehicles and facilities to reach their destinations (Federal Transit Administration 2003). Improvements in the public transportation links between urban and suburban areas result in a shift in the population from urban to suburban areas (Chau and $\mathrm{Ng}$ 1998). This reduces the disparities in land prices and helps to reduce congestion and other problems (Disney 1998). Despite the advantages of public transportation, the concept is still not popular in the Middle East, particularly within the Gulf Cooperative Council (GCC) countries.

The Sultanate of Oman, one of the six GCC countries, has less exposure to the different modes and services of public transport. Oman occupies the southeastern corner of the Arabian Peninsula with a total area of 310 thousand square $\mathrm{km}$ and a total population of 2.74 million (2007). Oman is the third largest country in the Arabian Peninsula and is divided into nine main administrative regions (governorates), of which Muscat (27 percent) and Al-Batinah (28 percent) account for more than half of the total population (Statistical Handbook of Oman 2008).

Despite catering to the largest population, the Al-Batinah region lacks a public transportation system for commuters. The situation is even worse in other regions of Oman except Muscat, the capital city, where large buses, micro-buses, and taxis are available. People either struggle for the few seats in shared taxis or depend on private cars. While unavailability of public transport causes inconvenience, the excessive dependence on private cars leads to heavy traffic, a large number of accidents, and high individual expenditure on transport. 
At this time, when public transport services attract significant attention from policy makers globally, why they are lacking in Oman is a major concern of this study. The implementation of public transport and its acceptability depends on the perception and attitude of citizens. This study reveals people's perceptions of public transport in Oman and identifies facilitators and barriers to such services.

\section{Review of Middle Eastern and Omani Public Transport}

The need to strengthen public transportation systems recently gained new momentum in the Middle East. The 1st UITP Congress for the Middle East and North Africa (MENA) region also stressed the importance of developing long-term ambitious plans to expand and develop the public transport sector.

A recent World Bank (2009) report observes serious capacity gaps in the urban and rural transport infrastructure of the MENA countries. Addressing such gaps could help in accelerating economic growth, regional integration, quality of life, and creation of jobs, in addition to reducing vulnerability to accidents, exclusion of people, and poverty in the region. This report observes that the MENA region, although it is far more urbanized than East Asia or South Asia, lacks development in public transport.

To overcome such weaknesses, some of the GCC countries have recently taken certain initiatives in this regard. Bahrain launched a BD 4.5 million (US\$11.9 million) public-private sector joint venture, the Arabian Cab Company (ACC), adding a fleet of 350 brand new "London cabs" to its existing pool (Bahrain Tribune 2008). This project is expected to boost the economy through regulation, competition, and growth in employment. Looking beyond the basic gains, Qatar is planning to launch electric-powered taxis and battery-powered public buses to acquire ecological and economical benefits (Altaqata 2009a). MidEast.ru (2009) reports that the Road and Transport Authority (RTA) in the UAE is planning to introduce a fleet of buses exclusively for women. Abu Dhabi has enriched its public transport infrastructure with taxis and buses and is offering free services on four routes (Altaqata 2009b). Sharjah aims to ease the travel woes of residents and daily commuters with 25 buses on three routes, which are expected to amount to a fleet of 172 buses on 18 routes (Altaqata 2009c).

Despite these efforts, 72 percent of UAE residents still feel that the public transport system is inadequate and are frustrated with prolonged waiting periods. Public transport usage in Dubai is only 6 percent, as compared to 65 percent in 
Singapore or 78 percent in Hong Kong. Gulf News (Dubai) recently reported that traffic congestion, the single biggest concern among Dubai's 1.44 million residents, inflicts yearly losses of AED4.6 billion (US\$1.25 billion) or 3.15 percent of the Emirate's AED146 billion (US\$39.8 billion) annual GDP (Altaqata, 2009d). The effects of the newly-introduced metro system are only beginning to be realized.

Problems with a lack of public transport and resulting initiatives are not limited to the Gulf region alone. Other countries are also facing serious problems due to the rapid growth in private vehicle ownership, inefficient public transport, and the deteriorating urban environment (Imran and Low 2005; Edvardsson 1998). Istanbul, facing similar serious transportation problems, has decided to build at least 1 $\mathrm{km}$ of metro annually to integrate its transport infrastructure comprising metro buses, underground metros, and city buses. There is mixed evidence, however, of its overall effects. In Yemen, the transport sector contributes 10-13 percent of GDP, of which 80 percent comes from public transportation. With 8 bus and 6 taxi companies operating between Yemeni cities, the sector offers 8,000 micro buses in the capital city of Sana'a alone (Altaqata, 2009e). Enquist et al. (2007) observe that public transportation in Sweden has been passing through three waves of development, namely production, service, and sustainability.

The situation of Oman is not noticeably different from that of the GCC countries. In order to create a demand for a public transport system and to reduce excessive reliance on private cars, Oman needs to take strong initiatives. Road accidents in Oman have also become a major concern to families and communities (AlQareeni 2008). Unfortunately, Oman had the highest fatality rate $(23.7 / 100,000$ pop.) in 1996 in the MENA region (Figure 1), and there has been no relief in the past 10 years, despite of advancements in vehicles and road safety measures (Table 1). Among the nine governorates, Al-Batinah records the highest number of fatalities caused by road accidents.

Table 1. Road Accidents and Fatalities in Oman (2001-2007)

\begin{tabular}{lccccc} 
& $\mathbf{2 0 0 7}$ & $\mathbf{2 0 0 6}$ & $\mathbf{2 0 0 5}$ & $\mathbf{2 0 0 3}$ & $\mathbf{2 0 0 1}$ \\
\hline Total Population & $2,743,000$ & $2,577,000$ & $2,509,000$ & $2,416,000$ & $2,341,000$ \\
Road Accidents & 8,816 & 9,869 & 9,247 & 9,460 & 10,197 \\
Fatalities & 650 & 550 & 548 & 490 & 428 \\
Fatalities/1,00,000 & 23.7 & 21.3 & 21.8 & 20.3 & 18.3 \\
\hline
\end{tabular}

Source: Statistical Year Book 2008, Issue 36, October 2008, Ministry of National Economy, Sultanate of Oman. 
Therefore, introduction of better modes of public transport is emerging as a public concern that could help in ensuring safety on the roads. Furthermore, there is a need to investigate road safety mechanisms, since transit users' perception of their safety is crucial to their decisions about whether or not to use public transport (Vogel and Pettinari 2002). Implementation and adoption of public transport could address concerns related to Oman's quickly depleting oil reserves and a need to support industrial development and tourism policies.

\section{Middle East \& North African Countries \\ Death / 100,000 pop.}

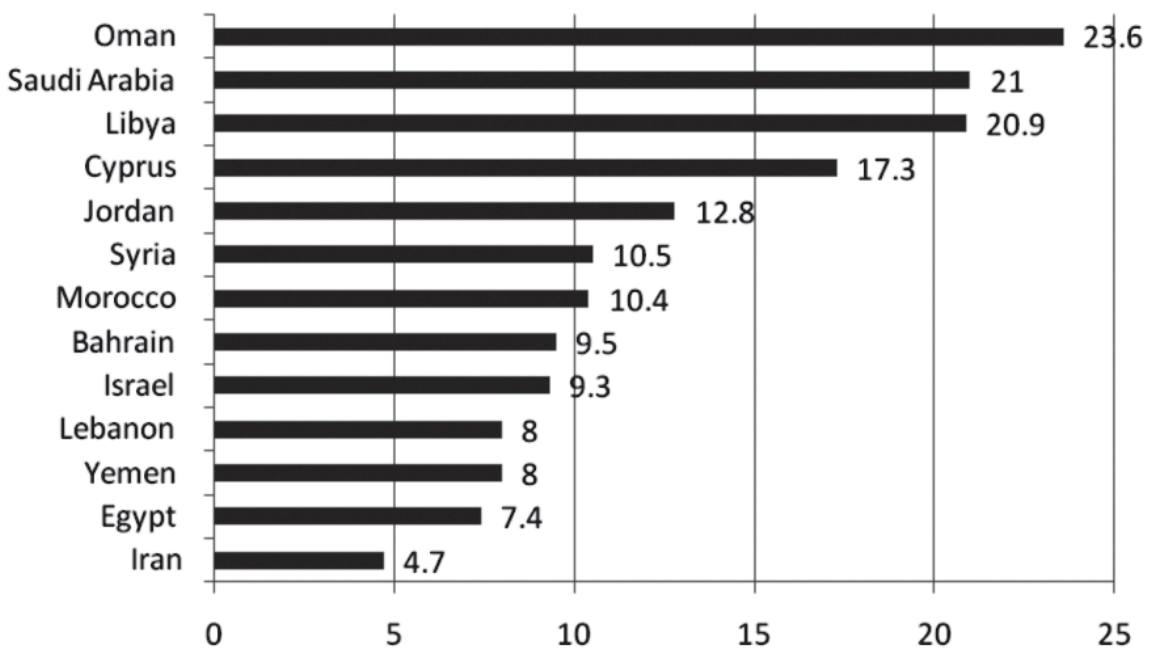

\section{Figure 1. Middle East and North Africa Fatality Risk (1996) Source: http://www.factbook.net/EGRF_Regional_analyses_Africa.htm}

Oman, in our belief, is currently making a beginning where it needs to design and offer different public transportation alternatives. The role of the Oman National Transport Company, established in 1972 and re-established in 1984 by Royal Decree 59/84 to operate public transport services in every part of the Sultanate, has been limited to long-haul public transportation services. For a majority of the public, shared taxis and buses are the current modes of public transport. Oman envisions a $200 \mathrm{~km}$ railway track for goods trains between the industrial cities of Sohar and Barka. This could possibly be extended to facilitate passenger transport. The Supreme Committee for Town Planning (SCTP) is preparing to launch a feasibility study covering the development of a National Railway Network. The sooner the initiatives start, the better will be the results. 
However, the marketing of products or services and their subsequent adoption are not independent of consumer perceptions. Service quality perceptions have been found to affect behavioral intentions to purchase and could be linked with the marketing efforts in the industry (Perez et al. 2007; Andreassen 1995; Boulding et al. 1993; Zeithaml 1988). Perceived performance, according to Andreassen (1995), is influenced by consumer perceptions of quality, the marketing mix, the brand name, and the image of the service provider. Andreassen (1995) associated some latent variables to reveal consumer perceptions of the quality of public transport services: safety, design /layout, location, quality of vehicles, availability, time spent in traveling, information about services, ticket systems, and price levels. According to Disney (1998), reliability, frequency, friendliness of services, cleanliness of interiors and exteriors comfort, ease of access, reasonable fares, and easy-to-understand timetables were found at the top of positive reasons for utilizing bus services in the UK.

A proper analysis of citizen perceptions of public transport services could help in measuring their perception about, and readiness towards, the adoption of public transport. This study aims to measure citizen perceptions of public transport services in Oman and their readiness to adopt them. We agree that the introduction of public transport is not new to Oman. Though it has existed for a significant period, it has not met its purpose. One of the real contributions of this study is the interrogation it makes of the socio-cultural norms and the physical conditions of the terrain and the behavioral implications that emerge as a result of cultural impediments and transit needs. The following sections specifically lay out the objectives and methodologies.

\section{Objectives of the Study}

The drive towards a decent public transport system in the Middle East is not baseless. It is the need of the hour. The above review indicates that the development of a decent public transportation system can ameliorate the transit difficulties faced by the public in Oman. It will not only help in supporting citizens in commuting but will also offer a safe mode of transportation to residents, as well as meet broad social, industrial, environmental, and national requirements. Assessing and revealing the general opinions, perceptions, needs, and expectations of the commuting public were identified as general objectives. More specifically, the following objectives were identified:

1. To assess the needs and perceptions of people towards the establishment of an effective public transportation system in Oman. 
2. To study resident characteristics such as usage behavior, experience, sharing habits, and other behavioral aspects about public transportation in Oman.

\section{Methodology}

The study was conducted in the form of a public needs assessment and opinion survey. The first phase of the study utilized desk research, observations, and informal discussions with knowledgeable individuals to assess the situation and arrive at some hypotheses to be tested, in line with the stated objectives. The hypotheses postulated are mentioned along with the test results later in Table 12. The second phase concentrated on the data collection and analysis.

Oman was home to around 2.74 million people in 2007 (including expatriates), of which 735,669 dwelt in the Al Batinah region (Statistical Year Book of Oman 2008). The Al Batinah region of Oman consists of 12 wilayats (districts): Sohar, Ar Rustaq, Shinas, Liwa, Saham, Al Khaburah, As Suwayq, Nakhal, Wadi Al Maawil, Al Awabi, Al Musanaah and Barka. The survey work was restricted to six wilayats: Sohar, Shinas, Liwa, Saham, Al Khaburah, and As Suwayq, as these areas contain the majority of the population and account for the mass influx of commuters to Sohar, the main industrial and port city where all the major industries, government directorates and ministries for the region are located.

The respondents from the six wilayats were selected using a convenience sampling approach. Individuals from different pockets such as residential areas, market places, government offices, and academic institutions were approached. However, although the selection was largely convenience-based, in order to maintain some randomness, efforts were made to cover every 5 th entity while choosing the respondents. Lunneborg (2007) argues that random sampling is almost always difficult and expensive and often prohibitive, and he states that though non-randomness severely limits, it does not completely preclude the possibility of gaining scientific knowledge from data contributed by a convenience sample.

A sample size of 196 was determined to be representative of the Al-Batinah region, based on a sample size calculator (http://www.surveysystem.com/sscalc.htm), with a confidence level of $95 \%$ and a confidence interval of $7 \%$. Responses were collected using structured questionnaires that contained both open-ended and closed-ended questions. Out of the total, 180 questionnaires were found complete for the purpose of analysis. 
The data were analyzed using SPSS-16 and Minitab-15. The reliability of the scales was tested using the Cronbach "alpha" score. Cronbach's alpha determines the internal consistency or average correlation of items in a survey instrument to gauge its reliability, where higher scores indicate higher reliability of the generated scale (Santos, 1999). The Cronbach alpha in this study scored 0.6160, somewhat lower than the most widely referred score of 0.7 (Nunnally 1978). However, an alpha of 0.5 or above is considered by Bowling (1997) as an indication of good internal consistency, while a much higher alpha score may suggest a high level of item redundancy (Streiner and Normal 1989). Hence, it can be argued that measurement scale used in this study met its purpose.

The profile of sample respondents is presented in Table 2. The profile indicates a balance in the number of car owners and their place of residence, gender, and marital status. However, it emerged that there was a higher representation of younger and more educated respondents. This happened by chance because, during the survey, younger and educated respondents revealed a higher interest and cooperation in participation. Others were found to be somewhat conservative in agreeing to our requests for their participation. Notwithstanding, it emerged that those who participated revealed higher propensity towards the acceptance of public transportation than the conservative ones.

Table 2. Profile of Sample Respondents $(\mathrm{N}=\mathbf{1 8 0} *)$

\begin{tabular}{|l|c|c|c|c|c|}
\hline Car Ownership & $\#(\%)$ & Driving License & $\#(\%)$ & Residence in & $\#(\%)$ \\
\hline Yes & $98(55.4)$ & Have & $113(64.9)$ & Proper city & $87(49.4)$ \\
\hline No & $79(44.6)$ & Don't have & $61(35.1)$ & Suburb & $89(50.6)$ \\
\hline Gender & & Nationality & & Work Status & \\
\hline Male & $93(52.5)$ & Omani & $160(90.4)$ & Employed & $109(61.6)$ \\
\hline Female & $84(47.5)$ & Expatriates & $17(9.6)$ & Unemployed ${ }^{* * *}$ & $68(38.4)$ \\
\hline Age & $129(72.9)$ & Unmarried & $100(56.5)$ & $\begin{array}{c}\text { Secondary or } \\
\text { higher }\end{array}$ & $156(88.1)$ \\
\hline$<30$ & $46(26.0)$ & Married & $74(41.8)$ & Primary & $9(5.1)$ \\
\hline $31-50$ & $2(1.1)$ & $\begin{array}{c}\text { Divorced/ } \\
\text { widowed }\end{array}$ & $3(1.7)$ & None & $12(6.8)$ \\
\hline$>51$ & & Marital Status & & & \\
\hline
\end{tabular}

* Mismatches in total represents missing responses.

** The figures in parenthesis represent valid percent.

*** These figures include students as well. 


\section{Analysis and Findings}

The descriptive analysis of the respondents' behavior reveals that a majority of them use their personal cars to get to work and only a few (17\%) use public transport services (Table 3). Table 3 and Table 4 jointly indicate that more people (15\%) use public transport for purposes other than getting to work. It is to be noted that the Al-Batinah region has a very limited access to buses or micro-buses and, therefore, public transport mostly implies the use of shared taxis.

Table 3. Means to Arrive at Work

\begin{tabular}{lcc} 
& Frequency & Percent \\
\hline Personal Car & 107 & 59.4 \\
Public Transport & 31 & 17.2 \\
Other & 39 & 21.7 \\
\hline
\end{tabular}

Table 4. Respondents' Status: Use of Public Transport Currently

\begin{tabular}{lcc} 
& Frequency & Percent \\
\hline Yes & 59 & 32.8 \\
No & 118 & 65.6 \\
\hline
\end{tabular}

A majority (67\%) of the respondents had experienced public transport services in the past (Table 5) either in Oman or abroad. Their experience was mainly limited to shared taxis, buses, and trains (Table 6).

Table 5. Respondents' Status: Use of Public Transport in the Past

\begin{tabular}{lcc} 
& Frequency & Percent \\
\hline Yes & 121 & 67.2 \\
No & 43 & 23.9 \\
\hline
\end{tabular}

Table 6. Respondents' Status: Public Transport Service Used

\begin{tabular}{lcc} 
& Frequency & Percent \\
\hline Shared Taxis & 46 & 25.6 \\
Bus & 37 & 20.6 \\
Train & 81 & 45.0 \\
Other & 6 & 3.3 \\
\hline
\end{tabular}

A majority of the people were not positive about their experience with public transportation services. Only 34 percent of the respondents revealed that their experience was pleasant (Table 7). This indicates that there exists some negative image of public transport. 
Table 7. Respondents' Experience with Public Transportation

\begin{tabular}{lcc} 
& Frequency & Percent \\
\hline Very Unpleasant & 9 & 5.0 \\
Unpleasant & 20 & 11.1 \\
Average & 79 & 43.9 \\
Pleasant & 43 & 23.9 \\
Very Pleasant & 14 & 7.8 \\
\hline
\end{tabular}

To compare the respondents' experience, cross tabulation was attempted between users and non-users (Table 8). No significant difference was observed between the experiences of the two groups $\left(\chi^{2}=6.503, p=0.165\right)$.

Table 8. Cross Tabulation between Current User Status and Experience

\begin{tabular}{|l|l|c|c|c|c|c|c|}
\cline { 3 - 8 } \multicolumn{2}{c|}{} & \multicolumn{6}{|c|}{ How you rate your experience? } \\
\cline { 3 - 8 } \multicolumn{2}{c|}{} & $\begin{array}{c}\text { Very } \\
\text { Unpleasant }\end{array}$ & Unpleasant & Average & $\begin{array}{c}\text { Very } \\
\text { Pleasant }\end{array}$ & Pleasant & Total \\
\hline Currently & Yes & 6 & 4 & 26 & 15 & 6 & 57 \\
using public & No & 3 & 16 & 53 & 27 & 8 & 107 \\
transport? & Total & 9 & 20 & 79 & 42 & 14 & 164 \\
\hline
\end{tabular}

Furthermore, cross tabulation was attempted between users-in-the-past and nonusers (Table 9). No significant difference was observed between the experience of users-in-the-past and non-users $\left(\chi^{2}=4.473, p=0.346\right)$.

Table 9. Cross Tabulation between Past Users Status and Experience

\begin{tabular}{|l|l|c|c|c|c|c|c|}
\cline { 3 - 8 } \multicolumn{2}{c|}{} & \multicolumn{6}{|c|}{ How you rate your experience? } \\
\cline { 3 - 8 } \multicolumn{2}{c|}{} & $\begin{array}{c}\text { Very } \\
\text { Unpleasant }\end{array}$ & Unpleasant & Average & $\begin{array}{c}\text { Very } \\
\text { Pleasant }\end{array}$ & Pleasant & Total \\
\hline $\begin{array}{l}\text { Used public } \\
\text { transit in }\end{array}$ & Yes & 5 & 13 & 63 & 27 & 10 & 118 \\
the past? & Total & 8 & 7 & 13 & 9 & 2 & 34 \\
\hline
\end{tabular}

Only a few respondents (5-6\%) depended highly (80-90\%) on public transportation services, while 17 percent of them did not experienced public transport at all (Table 10). 
Table 10. Respondents' Status: Percentage Use of Public Transport in Daily Activities

\begin{tabular}{ccc} 
Percent Use & Frequency & Percent \\
\hline 0 & 31 & 17.2 \\
10 & 31 & 17.2 \\
20 & 17 & 9.4 \\
30 & 23 & 12.8 \\
40 & 23 & 12.8 \\
50 & 19 & 10.6 \\
60 & 13 & 7.2 \\
70 & 9 & 5.0 \\
80 & 5 & 2.8 \\
90 & 5 & 2.8 \\
\hline
\end{tabular}

A majority of the respondents (84\%) dwelled in Al Batinah, Muscat, and Ad Dakhliyah governorates (otherwise accounting for $66 \%$ of the national population) out of a total of 12 governorates in Oman (Table 11). Their distribution across the nine governorates indicates the possibility of generalizing these findings to some extent for the whole of Oman.

Table 11. Respondents' Status: Place Where Maximum Life is Spent

\begin{tabular}{lcc}
$\begin{array}{l}\text { Administrative } \\
\text { Regions }\end{array}$ & Frequency & Percent \\
\hline Muscat & 28 & 15.6 \\
Al Batinah & 111 & 61.7 \\
Musandam & 1 & 0.6 \\
Adh Dhahriah & 5 & 2.8 \\
Ad Dakhliyah & 12 & 6.5 \\
Ash Sharqiyah & 6 & 3.3 \\
Al Wusta & 1 & 0.6 \\
Dhofar & 9 & 5.0 \\
Al Buraimi & 4 & 2.2 \\
90 & 5 & 2.8 \\
\hline
\end{tabular}

Inferential analyses were made to test the hypotheses. The One-Sample Wilcoxon Signed Rank Test was preferred over the t-test, since normality conditions were not assumed for the population. Since people were not very used to public transport and there was a dearth of such services, the population characteristics were assumed to be skewed in either direction. The Wilcoxon Signed Rank Test is more appropriate for cases in which the data level is ordinal or when the population is 
not believed to be approximately normally distributed (Whitley and Ball 2002; Groebner et al. 2005). The test checks the proposition whether the value of population median is less (as taken in our case), equal, or more than the hypothesized value (3 in our case).

The results arrived at after testing of hypotheses are expressed in Table 12. The acceptance of a proposition reveals that a majority (more than half) of the population is in agreement with that proposition. The mean and standard deviation scores also support the findings. Taking into account the results of hypothesis testing, it can be said for a majority of the population that people believe that public transportation is important for society. They believe that it adds convenience to their travels and is cost effective. People do not feel any discomfort in sharing taxis/buses with others, although they do find some socio-cultural barriers affecting the use of public transport in Oman. People prefer to use their own car to travel and would do so even if the price of oil were to double. However, they will use public transport if good-quality transport infrastructure is developed.

While considering the propositions in Table 12 that were rejected, we observe that many people do not perceive public transport to be safer in Oman than their private cars. Also, no clear consensus emerges among people in opinions about the sharing of public transport. There are mixed feelings indicating either acceptances or rejections. Similarly, they are divided in stating that public transport belittles their status. Therefore, some sections of the society assign higher status to traveling by personal cars and some prefer to travel by their own car for other reasons, as mentioned in Table 13, and are determined to use private cars (see the results for Hypothesis 12 in Table 12). However, some respondents have experienced public transport services in other GCC countries and have expressed a desire to use it if good transport infrastructure is developed.

Further to the collective hypotheses testing, a gender-wise cross tabulation was attempted to test the same propositions. The responses of the female population differ significantly from the males in certain areas. Females disagreed with the propositions that public transportation adds convenience to their travel $\left(\chi^{2}=\right.$ $18.731, p=0.002)$, that they do most of their traveling by public buses or taxis $\left(\chi^{2}\right.$ $=10.483, \mathrm{p}=0.033)$, that they do not feel any discomfort in public buses or taxis $\left(\chi^{2}=12.136, p=0.016\right)$, and that they do not mind sharing vehicles with male passengers $\left(\chi^{2}=51.375, p=0.000\right)$. 
Table 12. Wilcoxon Sign Rank Test Results (Test of Median $=3$ Versus Median $<3$ at $\alpha=5$ percent)

\begin{tabular}{|c|c|c|c|c|c|c|c|c|}
\hline No. & Hypotheses (Alternative) & $N$ & Wilcoxon & $p$ & Median & Mean & $S D$ & Result \\
\hline $\mathrm{H} 1_{A}:$ & $\begin{array}{l}\text { People believe that public } \\
\text { transportation is important } \\
\text { for society. }\end{array}$ & 162 & 501.0 & 0.00 & 1.500 & 1.64 & 0.88 & Accepted \\
\hline $\mathrm{H} 2_{\mathrm{A}}:$ & $\begin{array}{l}\text { People believe that public } \\
\text { transport adds convenience } \\
\text { to their travels. }\end{array}$ & 177 & 3368.0 & 0.00 & 2.500 & 2.66 & 1.36 & Accepted \\
\hline $\mathrm{H}_{\mathrm{A}}:$ & $\begin{array}{l}\text { People believe that public } \\
\text { transport brings cost } \\
\text { economy to them. }\end{array}$ & 176 & 2631.0 & 0.00 & 2.500 & 2.65 & 1.20 & Accepted \\
\hline $\mathrm{H} 4_{\mathrm{A}}:$ & $\begin{array}{l}\text { People believe that public } \\
\text { transport is safer than } \\
\text { private transport. }\end{array}$ & 177 & 6288.0 & 0.96 & 3.000 & 3.17 & 1.41 & Rejected \\
\hline $\mathrm{H} 5_{A}:$ & $\begin{array}{l}\text { People do most of their } \\
\text { travelling by public buses } \\
\text { or taxis. }\end{array}$ & 175 & 7980.0 & 1.00 & 3.500 & 3.44 & 1.42 & Rejected \\
\hline$H 6_{A}:$ & $\begin{array}{l}\text { People don't feel any dis- } \\
\text { comfort in sharing taxis/ } \\
\text { buses with others. }\end{array}$ & 174 & 3475.5 & 0.00 & 2.500 & 2.63 & 1.33 & Accepted \\
\hline $\mathrm{H}_{\mathrm{A}}:$ & $\begin{array}{l}\text { People don't mind taking } \\
\text { a taxi or public bus while } \\
\text { going to work. }\end{array}$ & 177 & 4854.0 & 0.16 & 3.000 & 2.88 & 1.32 & Rejected \\
\hline $\mathrm{H} 8_{\mathrm{A}}:$ & $\begin{array}{l}\text { People don't mind sharing } \\
\text { taxis with passengers of } \\
\text { the opposite sex. }\end{array}$ & 173 & 7033.0 & 0.99 & 3.000 & 3.22 & 1.47 & Rejected \\
\hline $\mathrm{H}{ }_{\mathrm{A}}:$ & $\begin{array}{l}\text { People find some socio- } \\
\text { cultural barriers affecting } \\
\text { the use of public transport } \\
\text { in Oman. }\end{array}$ & 174 & 2356.5 & 0.00 & 2.500 & 2.41 & 1.19 & Accepted \\
\hline $\mathrm{H} 10_{\mathrm{A}}:$ & $\begin{array}{l}\text { People consider public } \\
\text { transport a low class form } \\
\text { of travel. }\end{array}$ & 174 & 4810.5 & 0.39 & 3.000 & 2.97 & 1.35 & Rejected \\
\hline $\mathrm{H} 11_{\mathrm{A}}:$ & $\begin{array}{l}\text { People prefer to travel by } \\
\text { their own car. }\end{array}$ & 175 & 1527.5 & 0.00 & 1.500 & 1.89 & 1.93 & Accepted \\
\hline $\mathrm{H} 12_{\mathrm{A}}$ : & $\begin{array}{l}\text { People will prefer to use } \\
\text { their own car even if the } \\
\text { price of oil doubles in } \\
\text { Oman. }\end{array}$ & 177 & 1886.0 & 0.00 & 2.000 & 2.05 & 1.31 & Accepted \\
\hline $\mathrm{H} 13_{\mathrm{A}}$ : & $\begin{array}{l}\text { People have used public } \\
\text { transport services in other } \\
\text { GCC countries and have } \\
\text { found them good. }\end{array}$ & 175 & 5110.0 & 0.95 & 3.000 & 3.11 & 1.35 & Rejected \\
\hline H14 : & $\begin{array}{l}\text { People will prefer to use } \\
\text { public transport if good } \\
\text { quality transport infra- } \\
\text { structure is developed. }\end{array}$ & 178 & 1464.0 & 0.00 & 2.000 & 2.15 & 1.09 & Accepted \\
\hline
\end{tabular}

Responses were measured on Likert Scale from 1(Strongly Agree) to 5 (Strongly Disagree). 


\section{Table 13. Reasons for Using Personal Vehicles}

\begin{tabular}{lc} 
Reasons & Importance \\
\hline Personal convenience, comfort and flexibility & $* * * * *$ \\
Freedom, ease of use and quick maneuverability & $* * * * *$ \\
Privacy and safety & $* * * * *$ \\
Public transportation is not available & $* * * *$ \\
Cultural reasons & $* * *$ \\
To save money & $* *$ \\
To save time /to be in time & $* *$ \\
For recreational purposes especially listening to music & $* *$ \\
To avoid the heat & $*$ \\
For taking alternative routes to avoid traffic jams & $*$ \\
For shopping convenience & $*$ \\
Special occasions (tourism, wedding, crossing borders) or emergencies & $*$ \\
To avoid taxis that are prone to accidents (rash driving) & $*$ \\
To protect children from outside influences and cultural shocks & $*$ \\
To help friends, families and parents move & $*$ \\
\hline
\end{tabular}

Table 13 explores the reasons as to why people prefer to use their personal vehicles. The most important reasons that emerged out of open-ended questions were found to be personal convenience, flexibility and maneuverability, privacy and safety, and the unavailability of public transportation. Additional such reasons are given in Table 13. The relative importance has been reflected by using asterisks $\left.{ }^{*}\right)$, where a single asterisk against a reason records five respondents mentioning that reason.

Table 14 explores the suggestions from the public as to what can be done to improve public transportation services. The most important suggestions were introduction of railway services, standardization of prices, separation of public transportation for males and females, establishment of more public transport companies, and improvement in the infrastructure. More suggestions are mentioned in Table 14. Again, an asterisk against a suggestion records five respondents mentioning it. 


\section{Table 14. Suggestions for Improving Public Transportation Services}

Introduce trains

Standardize the prices for better control and affordability

Separate public rransportation for males and females

Plan for taxis driven by women for women (preferably in a different color)

Allow more public transport companies to operate

Increase the availability of buses/taxis and the number of stops

Improve roads, build over/under bridges to avoid jams

Devise better rules and regulations for drivers and public transport companies

$* * * * * * * *$

Put more number of good quality AC buses with better ergonomics

Develop local airports

Provide and adhere to the time schedules

Increase the awareness among citizens about public transportation

Evolve a better system of public transport

Increase the number of taxis and buses

Provide recreation and refreshments in buses

Impose taxes on private cars

Improve long-haul transport services

Introduction of buses should not affect the plight of taxi drivers

Drivers should be trained to have some working knowledge of English

Drivers should be polite

Drivers to carry badges revealing identity and authorization

24 /7 availability of public transport is to be ensured

Acceptable luggage limits and pricing policy should be there

Metering system in taxis to be introduced for price control

\section{Discussion}

The findings in the above section reveal that people in Oman are mainly dependent on their private cars for transit. The findings were challenged by a triangulation approach in which free discussions were made with some senior officials from public transport authorities, local industries, Ministry of Social Development, and from the society in general. It emerged that although some cultural issues impede the sharing of transportation, it is no longer an issue in the capital city Muscat (where people have started sharing public transport, even with those of the opposite sex), and there is enough competition between private and public sectors players, although not much regulated nor optimized to gain synergy.

The population density of Oman is low (approx. 8/ square km, 2003), and the population is scattered unevenly in the nine regions, which imposes a serious challenge to transport planners in offering specific solution for a particular region. People are open to using public transport, but are unable to reconcile how it could 
help them in their daily transits, ranging from their visits to offices, traditional shops, fish markets near the coast, and, more importantly, the hypermarkets from which they purchase most of their groceries. People argue that they will be unwilling to wait for buses/ taxis when the temperature outside, for almost six months, ranges between 40-50 degrees Celsius. On the behavioral side, people are basically addicted to using their private cars, while cars for some are a distinct social status symbol. To get rid of that mentality would be a real challenge for the marketers of public transport. Women, especially, are less willing to adopt public transport, as they feel more comfortable and secure in their personal cars.

Furthermore, traffic regulators need to control unexpected disturbances brought about by external and internal factors. External factors cover elements such as characteristics of transit vehicles, roadway or traffic flow impedance, random delays and unusual passenger demands; internal factors may include elements such as organization and management, scheduling, breakdowns, delays, etc. (Dridi et al. 2005). Going beyond the normal conditions, Liden and Edvardsson (2003) emphasize the design of service guarantees in public transport, especially when a negative industry reputation already exists. Oman will probably need to ensure a guaranteed public transport system to attract and retain customers who otherwise perceive public transport services negatively.

However, certain concerns such as fuel conservation, the increasing number of road accidents, and traffic congestion could support the drive towards public transport. Regulation of different modes and payment mechanisms and their seamless connectivity and interoperability needs multi-modal planning for effective public transport and would be a crucial aspect for its acceptance. Transit riders should not get stuck with a "what to do next" situation in order to reach their intended destinations. All of these demand policy initiatives at various levels.

\section{Conclusions}

To ensure the vitality of civic life, industry, and government, effective public transportation services are a must in every country. The use of public transport is growing in developed and developing countries alike. This paper has highlighted such efforts in the Middle East (especially in Bahrain, UAE, Yemen, and Qatar) and other countries such as Turkey and Sweden. Countries, such as Oman, need good public transportation options for commuters where people either struggle for seats in often difficult to find shared taxis or rely exclusively on their private cars. 
To offer any solution, the needs and expectations of the people have foremost to be taken into account.

After a survey, this paper attempts to secure the public perception towards public transport services in Oman. The descriptive analysis of the respondents' behavior reveals that a majority of them use their personal cars to get to work and only a few use public transport services. It is not that the people in Oman have not experienced public transport services in the past. They have, but their experience with public transport services has not been pleasant. Only a few respondents depend greatly on public transportation services, while some do not use public transport at all.

The testing of hypotheses reveals that people consider public transportation important for society and believe that public transport is convenient and cost effective. People do not feel any discomfort in sharing taxis/buses with others. People find some socio-cultural barriers affecting the use of public transport in Oman. They prefer to travel by their own cars and are sufficiently convinced of the merit of this mode of travel even if the price of oil doubles in Oman. However, they are willing to use public transport provided good transport infrastructure is developed. The female population does not find public transportation services convenient. They favor personal cars and dislike sharing taxis with males. The most common reasons for preferring personal vehicles are convenience, flexibility and maneuverability, privacy and safety, and the absence of public transportation.

Among the suggestions for improving public transportation services, the most common are the introduction of railway services, the standardization of prices, the separation of public transportation for males and females, the formation of more public transport companies, and improvement in infrastructure. All these factors can help the policy makers and transport authorities to devise well-acceptable public transport services in Oman. There is a pressing need to develop a national policy on public transportation that takes into account the identification and development of public transportation modes, routes, and services; their proper regulation protecting the interest of different service providers; provision of interoperability of transit modes and payment; addressing of socio-cultural barriers; and creation of public transport infrastructure that deals with the adverse climatic conditions. Success gained in this regard can help the country and its economy on many fronts. 


\section{Significance, Innovation, Limitation, and Further Research}

This research is significant for understanding the perceptions of public in Oman in particular and Islamic countries of the Gulf in general. Moreover, it has helped in forming a positive opinion and attitude among citizens about the benefits of sharing resources for transportation purposes and its easy acceptance and prevalence in society. The study is innovative from the perspective approach and possible implementation in Oman. It could help the nation carve out a long-term strategy of establishing viable public transport modes or alternatives, e.g. trams, waterways, and subterranean /general railways in the country, which could extend the domain of economic benefits from the common man to those in businesses and industries. Limitations on the overall applicability of our conclusions might have been imposed by the small sample size, higher representation of young and more educated respondents in the sample, use of convenience sampling, and possible respondent bias. Notwithstanding these, we believe that well planned and well implemented public transportation could help Oman in strengthening its cultural, educational, economical, and welfare bonds with the society. These areas open a wide scope to future researchers.

\section{References}

Al-Qareeni, Hamed bin Hashel. 2008. Traffic Safety Institute Systematic knowledge to enhance road safety. http://www.rop.gov.om/english/articlesdet. asp?articleid $=3$.

Altaqata. 2009a. Qatar public transport adopting new technologies. http://www. altaqata.com/newsDtls.php?id=1350.

Altaqata. 2009b. Long, hard commute becomes an easy journey in Abu Dhabi. http://www.altaqata.com/newsDtls.php?id=1924.

Altaqata. 2009c. Sharjah to launch public transport buses in May. http://www. altaqata.com/newsDtls.php?id=1472.

Altaqata. 2009d. Limited transport restricts public transport usage: RTA stresses hurdles to Dubai's public transport. http://www.altaqata.com/newsDtls. php?id=1932.

Altaqata. 2009e. Public Transport Sector in Yemen Needing Attention: An Ignored Sector Cries For Attention http://www.altaqata.com/newsDtls.php?id=1876. 
Andreassen, T. W. 1995. (Dis)satisfaction with public services: The case of public transportation. Journal of Services Marketing 9 (5): 30-41.

Bahrain Tribune. 2008. Bahrain public transport to get a BD4.5m boost. http:// www.menafn.com/qn_news_story_s.asp?Storyld=1093213580. 24.09.2008

Boulding, W., A. Kalra, R. Staelin, and V. Zeithaml. 1993. A dynamic process model of service quality: from expectations to behavioral intentions. Journal of Marketing Research 30: 7-27.

Bowling, A. 1997. Research Methods in Health. Buckingham: Open University Press.

Chau, K. W., and F. F. Ng. 1998. The effects of improvement in public transportation capacity on residential price gradient in Hong Kong. Journal of Property Valuation \& Investment 16 (4): 397-410.

Disney, J. 1998. Competing through quality in transport services. Managing Service Quality 8(2): 112-118.

Dridi, M., K. Mesghouni, and P. Borne. 2005. Traffic control in transportation systems. Journal of Manufacturing Technology Management 16 (1): 53-74.

Edvardsson, B. 1998. Causes of customer dissatisfaction - studies of public transport by the critical-incident method. Managing Service Quality 8(3): 189-197.

Enquist, B., M. Johnson, and C. Camén. 2005. Contractual governance for sustainable service. Qualitative Research in Accounting \& Management 2(1): 29-53.

Federal Transit Administration. 2003. The Public Transportation System Security and Emergency Preparedness Planning Guide. U.S. Department of Transportation Research and Special Programs Administration. http://transit-safety.fta. dot.gov/publications/security/PlanningGuide.pdf.

Groebner, D. F., P. W Shannon, P. C. Fry, and K. D. Smith. 2005. Business Statistics: A Decision Making Approach. New Jersey: Prentice Hall.

Imran, M., and N. Low. 2005. Sustainable urban transport in Pakistan: Fhreats and opportunities. Management of Environmental Quality: An International Journal 16 (5): 505-529.

Lunneborg, C. E. 2007. Convenience sample. In Blackwell Encyclopedia of Sociology, Ritzer, G. (ed.). Blackwell Publishing. 
Lidén, S. B., and B. Edvardsson. 2003. Customer expectations on service guarantees. Managing Service Quality 13(5): 338-348.

MidEast.ru. 2009. Bus service exclusively for women in UAE. http://www. en.mideast.ru/336/42107.

Perez, M. S., J. G. Abad, G. M. Marin Carrillo, and R. Sanchez Fernandez. 2007. Effects of service quality dimensions on behavioral purchase intentions- $A$ study in public-sector transport, Managing Service Quality 17 (2): 134-151.

Santos, J., and A. Reynaldo. 1999. Cronbach's Alpha: A tool for assessing the reliability of scales. Journal of Extension 37(2). http://www.joe.org/joe/1999april/ tt3.php.

Statistical Year Book of Oman. 2008. Ministry of National Economy, Sultanate of Oman. Issue 36, October 2008.

Tran, T., and B. H. Kleiner. 2005. Managing for excellence in Public transportation. Management Research News 28(11/12): 154-163.

Vogel, M., and J. Pettinari. 2002. Personal safety and transit: Paths, environments, stops, and stations. Final Report (\#CTS 02-05), Minneapolis, Minnesota: Center for Transportation Studies.

Whitley, E., and J. Ball. 2002. Statistics review 6: Nonparametric methods. Critical Care (6):509-513. http://ccforum.com/content/6/6/509.

World Bank. 2009. Overview: Transport Sector Brief. http://web.worldbank.org/ WBSITE/EXTERNAL/COUNTRIES/MENAEXT/0,,contentMDK:20532420 pag ePK:146736 piPK:226340 theSitePK:256299,00.html

Zeithaml, V. A. 1988. Consumer perceptions of price, quality and value: A meansend model and synthesis of evidence. Journal of Marketing 52: 2-22.

\section{Acknowledgment}

The authors acknowledge the anonymous reviewers for their critical comments and suggestions to improve this paper. Comments and suggestions made by Dr. Lance Bode of Sohar University have improved the manuscript. 


\section{About the Authors}

Dr. RAKesh Belwal (rbelwal@soharuni.edu.com) is Associate Professor in the Faculty of Business of Sohar University, Oman. He has wide experience in tertiarylevel teaching at different universities in India, Ethiopia, and Oman. His main research interests are in the areas of service marketing, e-governance, and retailing.

Dr. Shweta Belwal (shweta.belwal@gmail.com) is Assistant Professor in the Faculty of Business of Sohar University, Oman. She has also taught in Business programs at Addis Ababa University and Mekelle University in Ethiopia. Her main research interests are in the areas of marketing and human resource management. 